\title{
Penapisan dan potensi bakteri endofit asal tanaman Arecaceae sebagai agens pengendali hayati cendawan Pestalotiopsis sp. penyebab penyakit bercak daun pada kelapa kopyor (Cocos nucifera)
}

\author{
Selection and potency of endophytic bacteria from Arecaceae as biocontrol agents of \\ Pestalotiopsis sp. causing leaf spot diseae on kopyor coconut (Cocos nucifera)
}

\author{
Deden Dewantara ERIS ${ }^{1)}$, Abdul MUNIF ${ }^{2) *}$, Bonny PW SOEKARNO ${ }^{2)}$ \& Agus PURWANTARA ${ }^{1)}$ \\ ${ }^{1)}$ Pusat Penelitian Bioteknologi dan Bioindustri Indonesia, J1 Taman kencana No 1 Bogor 16128, Indonesia \\ ${ }^{2)}$ Departemen Proteksi Tanaman, Institut Pertanian Bogor, Jl Kamper, Kampus Darmaga, Bogor 16680
}

Diterima tgl 3 Januari 2017/ disetujui tgl 28 April 2017

\begin{abstract}
Kopyor is a recessive-gene-trait coconut that has a delicious taste and high prices. One of several major problems of kopyor coconut cultivation is leaf spot disease. Endophytic bacteria originated from Arecaceae can be used as a biocontrol agents to control the disease in a sustainable way. The objective of the research was to select endophytic bacteria isolated from Arecaceae roots and leaves such as Pejibaye (Bactris gasipaes), Oil Palm (Elaeis guinensis), Kopyor Coconut (Cocos nucifera), Sugar Palm (Arenga pinnata) and Nibung (Oncosperma filamentosa) as biocontrol agent of Pestalotiopsis sp. Fourty isolates of endophyte bacteria are not pathogen to plant or animal and human. There are seven best selected endophytic isolates that can inhibit Pestalotiopsis sp. Some of them have the ability to dissolve phosphate, produce IAA, chitinase, and fix nitrogen. Those isolates are EAKSS 502, EAKSS 507, EAKSS 509, EAKSS 510, EAAPN 237, EAONN 545 and EAKPN 201. EAKPN 201 is the best candidate as biocontrol agent againts Pestalotiopsis sp. with $64,4 \%$ inhibition of Pestalotiopsis sp. on antagonist test.
\end{abstract}

[Keywords: Palmae, plant pathogen, antagonist agents, antibiotict test]

\begin{abstract}
Abstrak
Kopyor adalah kelapa dengan sifat gen resesif yang memiliki rasa lezat dan harga yang tinggi. Salah satu masalah utama dalam pembudidayaan kelapa kopyor adalah penyakit bercak daun. Bakteri endofitik yang berasal dari tanaman Arecaceae dapat digunakan sebagai agens pengendali hayati dalam mengendalikan penyakit secara berkelanjutan. Penelitian ini bertujuan
\end{abstract}

untuk menseleksi bakteri endofit yang berasal dari akar dan daun tanaman Arecaceae seperti Pejibaye (Bactris gasipaes), Kelapa Sawit (Elaeis guinensis), Kopyor Coconut (Cocos nucifera), Aren (Arenga pinnata) dan Nibung (Oncosperma filamentosa) yang berfungsi sebagai agen biokontrol Pestalotiopsis sp. Empat puluh isolat bakteri endofit non patogen terhadap tumbuhan atau hewan dan manusia berhasil diperoleh. Tujuh isolat bakteri endofit memiliki daya penghambatan terbaik terhadap cendawan Pestalotiopsis sp. Beberapa isolat memiliki kemampuan dalam melarutkan fosfat, memproduksi IAA, kitinase dan mengikat nitrogen. Ketujuh isolat tersebut yaitu isolat EAKSS 502, EAKSS 507, EAKSS 509, EAKSS 510, EAAPN 237, EAONN 545 dan EAKPN 201 EAKPN 201 adalah kandidat terbaik sebagai agen biokontrol untuk Pestalotiopsis sp. dengan penghambatan sebesar $64,4 \%$ pada uji antagonis.

[Kata kunci: Palem-paleman, patogen tanaman, antagonis, uji antibiosis]

\section{Pendahuluan}

Tanaman kelapa merupakan salah satu komoditas perkebunan utama di Indonesia. Pada areal pertanaman kelapa sering kali ditemukan tanaman dengan buah kelapa abnormal berupa daging buah yang terlepas dari tempurungnya atau yang dikenal dengan kopyor. Kelapa kopyor memiliki rasa yang nikmat dan harga jual yang tinggi. Untuk mendapatkan tanaman kelapa dengan persentase kopyor maksimal, maka dikembangkan perbanyakan bibit dengan teknik kultur jaringan (Sukmoto, 2001).

Salah satu hambatan dalam budidaya kelapa kopyor baik konvensional maupun kultur jaringan

\footnotetext{
${ }^{*}$ Penulis korenspondensi: munif73@gmail.com
} 
adalah penyakit bercak daun. Penyakit bercak daun merupakan penyakit yang paling sering ditemukan di pembibitan dan tanaman kelapa usia muda. Kittimorakul et al., (2013) menyatakan bahwa tingkat keparahan penyakit bercak daun pada Arecaceae memiliki kisaran antara 22,38-61,01\%. Di Malaysia, penyakit bercak daun dilaporkan disebabkan oleh Curvularia lunata dan Curvularia maculans (Daungsa-ard et al., 2011), sedangkan di Venezuela disebabkan oleh genus Pestalotiopsis (Pestalotiopsis palmarum dan Pestalotiopsis glandicola (Suwannarach et al., 2013). Di Bogor, serangan patogen bercak daun pada kelapa kopyor utamanya disebabkan oleh Pestalotiopsis sp. Pada pengamatan pendahuluan di blok endemik bercak daun, patogen bercak daun mampu menyebabkan keparahan penyakit hingga $70 \%$. Serangan patogen bercak daun menyebabkan penurunan kemampuan produksi, penurunan kualitas bibit tanaman sehingga perlu dikelola dengan baik karena bila dibiarkan dapat menyebabkan kematian tanaman (Kittimorakul et al., 2013).

Pengendalian patogen Pestalotiopsis sp. saat ini bertumpu pada penggunaan pestisida sintetik sebagai pengendalian utama yang dalam jangka panjang dapat menyebabkan kerusakan ekosistem. Salah satu solusi pengendalian cendawan penyebab penyakit bercak adalah pengendalian hayati. Pengendalian hayati memiliki keunggulan yakni ramah terhadap lingkungan. Salah satu bentuk pengendalian hayati adalah aplikasi bakteri endofit. Bakteri endofit hidup dalam jaringan tanaman dan bersimbiosis dengan tanaman bahkan dapat berfungsi sebagai agens pengendali hayati. Bakteri endofit yang baik sebagai agens pengendali hayati adalah bakteri endofit yang mampu menghambat perkembangan patogen, merangsang respon ketahanan tanaman, sekaligus meningkatkan respon pertumbuhan bagi tanaman (plant growth promoter) diantaranya melalui penyediaan fosfat dan nitrogen bagi tanaman, produksi hormon IAA, dan serta kemampuan berkembang pada kondisi terbatas (Hallmann et al., 2001; Etesami et al., 2015). Salah satu sumber bakteri endofit adalah tanaman famili Arecaceae.

Informasi mengenai potensi bakteri endofit pada tanaman Arecaceae sebagai agens pengendali hayati masih sangat terbatas, sehingga perlu dikaji lebih luas. Beberapa tanaman yang termasuk ke dalam famili Arecaceae yang berpotensi sebagai sumber bakteri endofit unggul diantaranya Kelapa Kopyor (Cocos nucifera), Pejibaye (Bactris gasipaes), Aren (Arenga pinnata), dan Kelapa Sawit (Elaeis guinensis). Tanaman Arecaceae lain yang belum banyak dikaji adalah Nibung (Oncosperma filamentosa). Penelitian ini bertujuan untuk memperoleh bakteri endofit dari perakaran dan daun tanaman kelompok Arecaceae yaitu Pejibaye, Kelapa Sawit, Kelapa Kopyor, Aren, dan Nibung, yang berpotensi sebagai agens pengendali hayati cendawan penyebab bercak daun Pestalotiopsis sp.

\section{Bahan dan Metode}

Isolasi, peremajaan bakteri endofit dan seleksi bakteri endofit potensial

Sebanyak 656 isolat bakteri endofit berhasil diisolasi (Eris et al., 2017) kemudian diremajakan di dalam tabung berisi $9 \mathrm{ml}$ Nutrient Broth (NB) dan diinkubasi selama 24 jam. Setelah masa inkubasi selesai, isolat-isolat dalam media cair digunakan pada pengujian. Selain itu masingmasing sebanyak satu lup suspensi isolat bakteri endofit dikulturkan kembali pada NA dalam tabung untuk pemeliharaan dan persediaan.

Kultur patogen penyebab penyakit bercak daun Pestalotiopsis sp. yang telah dimurnikan mengikuti Rahman et al. (2013) dijadikan bahan dalam pengujian kemampuan antagonis bakteri endofit terisolasi. Inokulum cendawan Pestalotiopsis sp. berdiameter $10 \mathrm{~mm}$ berusia 7 hari diletakkan di tengah-tengah cawan Petri. Delapan buah kertas saring steril berdiameter 10 $\mathrm{mm}$ ditaruh mengelilingi inokulum cendawan Pestalotiopsis sp. yang kemudian ditetesi $50 \mu \mathrm{L}$ suspensi masing-masing isolat bakteri endofit berusia 24 jam (Munif et al., 2012). Setelah 7 hari masa inkubasi, dilakukan pemilihan terhadap isolat yang memiliki daya penghambatan pertumbuhan miselium cendawan Pestalotiopsis sp.. Isolat-isolat bakteri endofit terpilih selanjutnya dikarakterisasi fisiologinya.

\section{Uji keamanan hayati}

Uji keamanan hayati dilakukan untuk mengeliminasi bakteri endofit yang berpotensi sebagai patogen pada tanaman, hewan dan manusia. Pengujian ini meliputi uji hipersensitivitas kemudian dilanjutkan dengan uji hemolisis. Uji hipersensitivitas dilakukan dengan menyuntikkan $1 \mathrm{~mL}$ suspensi bakteri endofit $\left(10^{8}\right.$ $\mathrm{CFU} / \mathrm{mL}$ ) diantara tulang daun tanaman tembakau (Nicotiana tabacum L.) berusia 3 bulan (Schaad et al., 2001). Pengamatan dilakukan setelah 48 jam terhadap jaringan daun yang diberi perlakuan penyuntikan. Bila terdapat gejala kematian jaringan berupa klorosis atau nekrosis maka isolat bakteri endofit yang diujikan berpotensi sebagai patogen. Uji hemolisis dilakukan dengan cara menumbuhkan isolat-isolat bakteri endofit terpilih pada media Agar Darah yang mengandung darah kambing 5\% (v/v). Setelah 2 hari inkubasi dilakukan pengamatan pertumbuhan koloni. Zona bening atau perubahan warna yang timbul di sekitar koloni bakteri menunjukkan isolat bakteri endofit tersebut berpotensi sebagai patogen pada hewan dan manusia (Suardana et al., 2014). Isolatisolat bakteri endofit yang tidak berpotensi patogen digunakan pada pengujian selanjutnya.

\section{Uji antibiosis}

Uji antibiosis bakteri endofit dilakukan dengan cara satu lup isolat bakteri endofit digoreskan tegak 
lurus pada bagian tengah cawan berisi media PDA. Inokulum kultur patogen Pestalotiopsis sp. berdiameter $10 \mathrm{~mm}$ diletakkan di kedua sisi isolat bakteri endofit yang diujikan. Cawan berisi kultur mikrob tersebut kemudian diinkubasi pada suhu ruang hingga hari ke-7 untuk selanjutnya dilakukan pengamatan (Munif et al., 2012 ). Pengamatan dilakukan terhadap daya penghambatan pertumbuhan miselium cendawan dengan mengukur jari-jari pertumbuhan koloni. Daya penghambatan pertumbuhan miselium cendawan dihitung dengan formula ((R1-R2)/R1) $\mathrm{x} 100 \%$, R1 merupakan jari-jari koloni cendawan patogen yang menjauhi koloni bakteri dan R2 adalah jari-

jari koloni cendawan patogen yang mendekati koloni bakteri (Gambar 1).

\section{Karakterisasi fisiologi bakteri endofit terpilih}

Bakteri endofit yang unggul sebagai agens pengendali hayati, selain memiliki daya penghambatan yang kuat terhadap cendawan diharapkan memiliki karakter fisiologi yang mendukung pertumbuhan tanaman diantaranya kemampuan melarutkan fosfat, produksi hormon auksin (IAA), produksi enzim kitinase dan kemampuan penambatan nitrogen. Tujuh isolat dengan daya penghambatan pertumbuhan cendawan Pestalotiopsis sp. terkuat pada uji antagonis (kultur ganda) diuji karakter fisiologi pendukung pertumbuhan melalui serangkaian pengujian meliputi uji pelarutan fosfat, uji produksi IAA, uji produksi kitinase dan uji penambat nitrogen.

\section{Uji pelarutan fosfat}

Isolat bakteri endofit digoreskan pada cawan Petri berisi media agar Pikovskaya. Pengamatan dilakukan terhadap "holozone" atau zona bening yang terbentuk di sekitar koloni bakteri pada media agar akibat aktivitas pelarutan fosfat. Pengujian dilakukan dengan tiga ulangan, lebar zona bening yang terbentuk diukur (Sarker et al., 2014). Pengamatan dilakukan setelah 3 hari masa inkubasi.

Uji produksi hormon auksin (Indole Acetic Acid/IAA)

Sebanyak $5 \mathrm{~mL}$ kultur bakteri endofit (24 jam) ditumbuhkan pada $100 \mathrm{~mL}$ media cair Nutrient Broth (NB) yang mengandung $0,1 \%$ DLTryptophan (w/v). Kultur cair tersebut digojok pada penggoyang (shaker) selama 48 jam (kecepatan $125 \mathrm{rpm}$ ). Kultur cair selanjutnya disentrifugasi selama 10 menit (kecepatan 10.000 rpm). Selanjutnya, sebanyak $1 \mathrm{~mL}$ supernatan dicampur dengan $4 \mathrm{~mL}$ reagen Salkowski. Pengujian dilakukan dengan 2 kali ulangan, sementara itu nilai IAA diestimasi dengan spektrofotometer pada panjang gelombang $535 \mathrm{~nm}$ (Ghevariya \& Desai, 2014).

\section{Uji produksi kitinase}

Uji produksi kitinase dilakukan pada media agar diperkaya dengan koloidal kitin. Media agar kitin yang digunakan dalam pengujian ini terdiri dari koloidal kittin $4 \mathrm{~g}, \mathrm{MgSO}_{4} \cdot 7 \mathrm{H}_{2} \mathrm{O} \quad 0,5 \mathrm{~g}$, $\mathrm{K}_{2} \mathrm{HPO}_{4} 0,7 \mathrm{~g}, \mathrm{KH}_{2} \mathrm{PO}_{4} 0,3 \mathrm{~g}, \mathrm{FeSO}_{4} .7 \mathrm{H}_{2} \mathrm{O} 0,01 \mathrm{~g}$, $\mathrm{MnCl}_{2}$ 0,001 g, dan Agar $20 \mathrm{~g}$ dilarutkan dalam akuades yang mengandung $0,03 \%$ Yeast extract $(\mathrm{w} / \mathrm{v})$. Sebanyak 1 lup inokulasi isolat bakteri endofit berumur 3 hari, ditumbuhkan pada media kitin agar didalam cawan Petri yang kemudian diinkubasi selama 3 hari. Bakteri endofit yang mampu memproduksi kitinase menunjukkan zona bening di sekitar koloni. Koloni bakteri yang menunjukkan kemampuan produksi enzim kitinase terbaik ditunjukkan dengan zona bening yang luas (Hariprasad et al., 2011). Pengamatan dilakukan setelah 3 hari masa inkubasi dengan mengukur zona bening yang terbentuk.

\section{Uji penambatan nitrogen}

Pengujian kemampuan menambat nitrogen dilakukan dengan menginokulasikan isolat bakteri endofit pada media bebas nitrogen. Pengujian dilakukan dengan menggunakan media bebas nitrogen Nitrogen Free Broth (Asam malat 5,0 g, K2HPO4 0,6 g, KH2PO4 1,8 g, MgSO4.7 $\mathrm{H}_{2} \mathrm{O} 0,2$ g, $\mathrm{NaCl} 0,1 \mathrm{~g}, \mathrm{CaCl}_{2} .2 \mathrm{H}_{2} \mathrm{O} 0,2 \mathrm{~g}$, FeEDTA 0,066 $\mathrm{g}, \mathrm{KOH} 4,5 \mathrm{~g}$, Bromo Thymol Blue $2 \mathrm{~mL}$, mikronutrien $2 \mathrm{~mL}$, akuades $1 \mathrm{~L}$, pH 5,8 semi padat). Kemampuan mikroba endofit dalam menambat nitrogen ditandai dengan terbentuknya pelikel. Mikroba dengan pelikel yang paling tegas diamati serta dikoleksi (Suriaman, 2010). Pengamatan terbentuknya pelikel dilakukan pada hari ke-3 setelah inokulasi (HSI).

\section{Analisis data}

Rancangan percobaan pada pengujian antagonis dilakukan menggunakan Rancangan Acak Lengkap (RAL) dengan 3 ulangan. Data penelitian dianalisis ragam (ANOVA) dengan bantuan perangkat lunak SAS 9.1 dan data yang bebeda nyata diuji lanjut menggunakan uji jarak berganda Tukey pada tingkat kepercayaan 95\%.

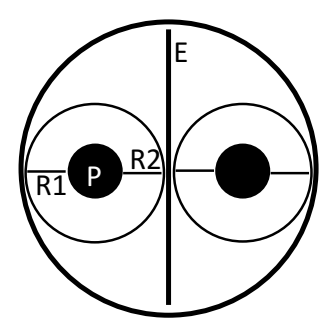

Gambar 1. Ilustrasi uji antibiosis secara invitro menggunakan teknik kultur ganda (E: bakteri endofit; P: cendawan Pestalotiopsis sp.).

Figure 1. Ilustration of antagonist test by dual culture technique (E: endophyte bacteria; $P$ : Pestalotiopsis sp.) 


\section{Hasil dan Pembahasan}

Isolasi, seleksi bakteri endofit potensial dan uji keamanan hayati

Sebanyak 64 isolat dari 656 isolat bakteri endofit yang berhasil diisolasi, mampu menghambat pertumbuhan cendawan Pestalotiopsis sp. Isolat-isolat tersebut terdiri dari 51 isolat bakteri endofit akar dan 13 isolat bakteri endofit daun (Tabel 1). Bakteri endofit yang terseleksi selain menunjukkan daya penghambatan terhadap cendawan penyebab bercak daun juga menunjukkan kemampuan pelarutan fosfat. Selanjutnya 64 isolat bakteri endofit yang diperoleh, diuji keamanan hayati melalui uji hipersensitivitas tembakau dan uji hemolisis pada media agar darah. Hasil pengamatan uji hipersensitivitas pada tembakau menunjukkan 54 isolat tidak bersifat patogen pada tanaman. Lima puluh empat isolat bakteri endofit selanjutnya diuji hemolisis pada media agar darah. Hasilnya diperoleh sebanyak 40 isolat bakteri endofit potensial yang tidak bersifat patogen pada hewan dan manusia (Tabel 1).

Patogen penyebab bercak pada kelapa kopyor yang berhasil diperoleh dari lapangan berkorelasi dengan patogen utama penyebab bercak pada tanaman palem-paleman yakni cendawan Pestalotiopsis sp. (Gambar 2). Konidia cendawan Pestalotiopsis sp. memiliki ukuran 15,6-31,2 $\times$ 4,6-6,1 $\mu \mathrm{m}$ dengan sel di tengah (median cell) berwarna kecoklatan. Embelan pada bagian apikal (apical appendage) berjumlah 1-3 dengan panjang antara 5,4-28,2 $\mu \mathrm{m}$ (Liu et al., 2007). Berdasarkan pengamatan gejala serangan patogen Pestalotiopsis sp. diawali dengan bercak berwarna kecoklatan, yang dilingkupi halo berwarna kekuningan. Bercak berkembang dan jaringan terserang di bagian tengah semakin berwarna coklat kehitaman kadang kala bercak tersebut bergabung dan membentuk hawar serta sering dijumpai adanya aservulus. Bercak-bercak tersebut dapat bergabung dan membentuk hawar.

Bakteri endofit yang digunakan sebagai agens pengendali hayati harus merupakan mikroorganisme yang aman bagi tumbuhan maupun hewan dan manusia (bersifat non patogenik). Bakteri patogen memiliki kemampuan untuk menghasilkan zat yang menyebabkan kerusakan pada sel tumbuhan maupun sel darah merah pada hewan dan manusia.

Respon positif pada uji hipersensitivitas berupa gejala nekrosis pada jaringan daun tembakau, menunjukkan potensi bakteri endofit yang diujikan sebagai patogen tumbuhan. Demikian pula respon positif berupa perubahan warna atau menjadi bening disekitar koloni bakteri endofit yang diujikan pada media agar darah menunjukkan potensi isolat bakteri endofit yang diujikan sebagai patogen pada hewan dan manusia.

Bakteri endofit yang bersifat patogen pada hewan dan manusia mampu menghasilkan racun yang dapat merubah permiabilitas sel, menyebabkan sel menjadi rentan yang dikenal sebagai hemolisin (Mudatsir, 2014). Hemolisin bakteri menyebabkan hemolisis. Terdapat 3 jenis hemolisis yaitu Beta hemolisis ( $\beta$ ), Alpha hemolisis $(\alpha)$ dan Gamma hemolisis $(\gamma)$. Berdasarkan pengamatan, beberapa isolat bakteri endofit mampu membentuk $(\beta)$ hemolisis atau disebut hemolisis total, terdapat zona bening yang jelas, dan transparan pada media agar darah mengelilingi koloni bakteri (data tidak ditunjukkan). Sementara itu bakteri endofit yang mengeluarkan hemolisin dan membentuk alpha hemolisis akan memunculkan warna kehijauan atau kecoklatan sekitar koloni pada media agar darah (Ariyanti, 2010; Suardana et al., 2014).

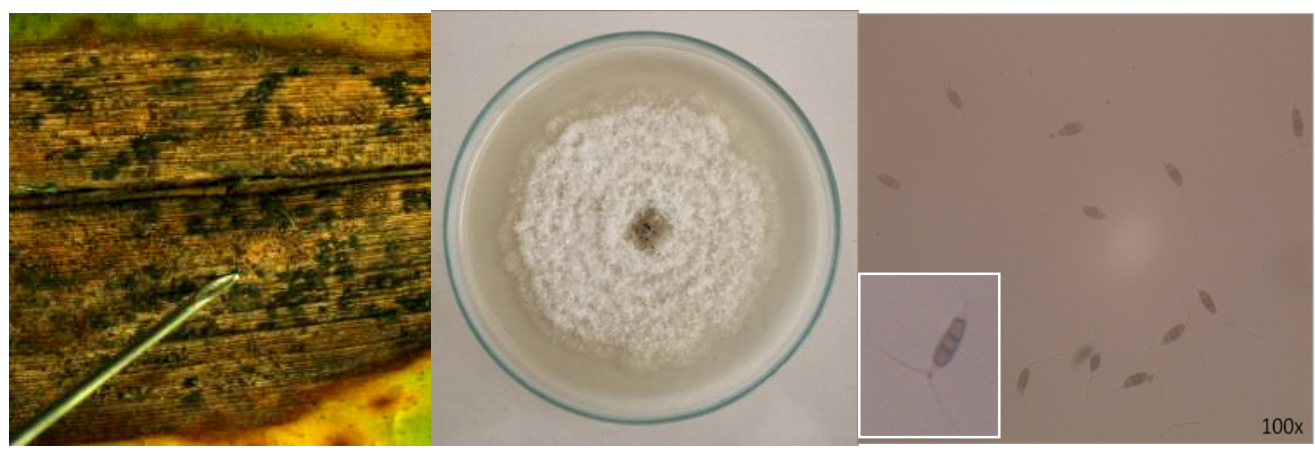

Gambar 2. Gejala penyakit (kiri), hasil isolasi (tengah) dan konidia Pestalotiposis sp. (kanan).

Figure 2. Symptoms of the disease (left), fungal isolates (center) and conidia of Pestalotiopsis sp. (right). 
Tabel 1. Jumlah isolat bakteri endofit yang diperoleh pada seleksi awal bakteri endofit potensial, uji Hipersensitivitas (HR) dan uji Hemolisis.

Table 1. A number of endophytic bacteria which were selected by early selection test of potential endophytic bacteria, hypersensitivity test (HR) and hemolytic test.

\begin{tabular}{|c|c|c|c|c|c|}
\hline \multirow[t]{2}{*}{$\begin{array}{l}\text { Sumber bakteri endofit/ } \\
\text { Origin of endophytic bacteria }\end{array}$} & \multirow{2}{*}{$\begin{array}{l}\text { Seleksi awal bakteri endofit } \\
\text { potensial/ } \\
\text { Early selection of potential } \\
\text { endophytic bacteria }\end{array}$} & \multicolumn{2}{|c|}{$\begin{array}{c}\mathrm{Uji} \\
\text { Hipersensitivitas } \\
\text { /HR test }\end{array}$} & \multicolumn{2}{|c|}{$\begin{array}{l}\text { Uji Hemolisis/ } \\
\text { Hemolytic test }\end{array}$} \\
\hline & & + & - & + & - \\
\hline \multicolumn{6}{|l|}{$\begin{array}{l}\text { Bakteri endofit akar /root endophyte } \\
\text { bacteria }\end{array}$} \\
\hline Pejibaye (B. gasipaes) & 11 & 6 & 5 & 1 & 4 \\
\hline Kelapa Sawit (E. guinensis) & 15 & - & 15 & 1 & 14 \\
\hline Kelapa Kopyor (C. nucifera) & 9 & 2 & 7 & 2 & 5 \\
\hline Aren $(A$. pinnata $)$ & 11 & - & 11 & 3 & 8 \\
\hline Nibung $(O$. filamentosa) & 5 & - & 5 & 3 & 2 \\
\hline \multicolumn{6}{|l|}{$\begin{array}{l}\text { Bakteri endofit daun /leaf endophyte } \\
\text { bacteria }\end{array}$} \\
\hline Pejibaye (B. gasipaes) & 4 & 1 & 3 & 2 & 1 \\
\hline Kelapa Sawit (E. guinensis) & 5 & - & 5 & 1 & 4 \\
\hline Kelapa Kopyor (C. nucifera) & 1 & 1 & - & - & - \\
\hline Aren $(A$. pinnata $)$ & 3 & - & 3 & 1 & 2 \\
\hline Nibung (O. filamentosa) & - & - & - & - & - \\
\hline Total isolat & 64 & 10 & 54 & 14 & 40 \\
\hline
\end{tabular}

\section{Pengujian antibiosis}

Sebanyak 40 isolat bakteri endofit terseleksi diuji dan 7 isolat diantaranya menunjukkan daya penghambatan pertumbuhan miselium cendawan Pestalotiopsis sp. terbesar. Isolat tersebut yaitu bakteri endofit asal kelapa kopyor EAKPN 201 dengan daya hambat sebesar $64,4 \%$, isolat bakteri asal kelapa sawit EAKSS 509 sebesar 36,1 \%, isolat EAKSS 502, EAKSS 510 dan EAKSS 515 sebesar 33,3\%, isolat bakteri asal aren dan nibung yaitu EAAPN 237 dan EAONN 545 sebesar 33,3 $\%$. Sedangkan 3 daya penghambatan pertumbuhan miselium Pestalotiopsis sp. terkecil diperoleh pada pengamatan isolat bakteri asal pejibaye EAPJN 207 sebesar 9,92\%, isolat bakteri asal aren EAAPN 557 sebesar 9,57\%, isolat bakteri asal kelapa kopyor dan kelapa sawit EAKPS 503 dan EAKSS 532 dengan nilai yang sama yakni sebesar 8,61\% (Gambar 3).

Bakteri endofit potensial mensekresikan senyawa yang berpotensi toksik terhadap cendawan penyebab bercak daun. Penghambatan pertumbuhan hifa cendawan Pestalotiopsis sp. ditandai dengan adanya zona hambat, perubahan dinding sel hifa menjadi berwarna gelap, perubahan struktur hifa menjadi bengkak menyerupai klamidospora serta terjadi pemendekan sel hifa. Hal ini sesuai dengan laporan Leelasuphakul et al., (2008) yang menyatakan penghambatan bakteri terhadap perkembangan hifa cendawan dapat berupa perubahan warna dinding sel hifa menjadi berwarna gelap, struktur hifa menjadi bengkak menyerupai klamidospora dan pemendekan sel.
Cendawan Pestalotiopsis sp. merupakan cendawan yang mampu memproduksi beragam senyawa metabolit. Metabolit tersebut diantaranya senyawa alkaloids, terpenoids, isocoumarin, coumarins, chromones, quinones, semiquinones, peptides, xanthones, xanthone derivatives, phenols, phenolic acids, dan lactones (Evidente et al., 2012). Metabolit berupa kelompok phenol yang bersifat fitotoksin adalah pestaloside.

Oxysporone, pestalopyrone, pestalotin $A$ dan $B$, hydroxypestalotin dan hydroxypestalopyron merupakan metabolit yang bersifat toksik yang berasal dari kelompok lactone (Nagata et al., 1992; $\mathrm{Xu}$ et al., 2010; Evidente et al., 2012). Dalam pengujian antibiosis dengan teknik kultur ganda, metabolit sekunder Pestalotiopsis sp. yang memiliki sifat antibiotik yang lebih kuat diduga sangat mempengaruhi variasi daya penghambatan pertumbuhan cendawan oleh isolat-isolat bakteri endofit.

\section{Karaterisasi fisiologi bakteri endofit terpilih}

Tujuh isolat bakteri endofit potensial diuji karakter fisiologi pendukung pertumbuhan tanaman. Isolat-isolat tersebut yaitu isolat EAKPN 201, EAKSS 509, EAKSS 502, EAKSS 510, EAAPN 237, EAONN 545, dan EAKSS 507. Pengujian karakter fisiologi pendukung pertumbuhan tanaman meliputi uji pelarutan fosfat, uji produksi IAA, uji produksi kitinase dan uji penambat nitrogen (Tabel 2).

Isolat-isolat bakteri endofit tersebut menunjukkan kemampuan pelarutan fosfat, produksi auksin, sekresi kitinase dan kemampuan penambatan nitrogen yang mendukung bagi perkembangan tanaman. 


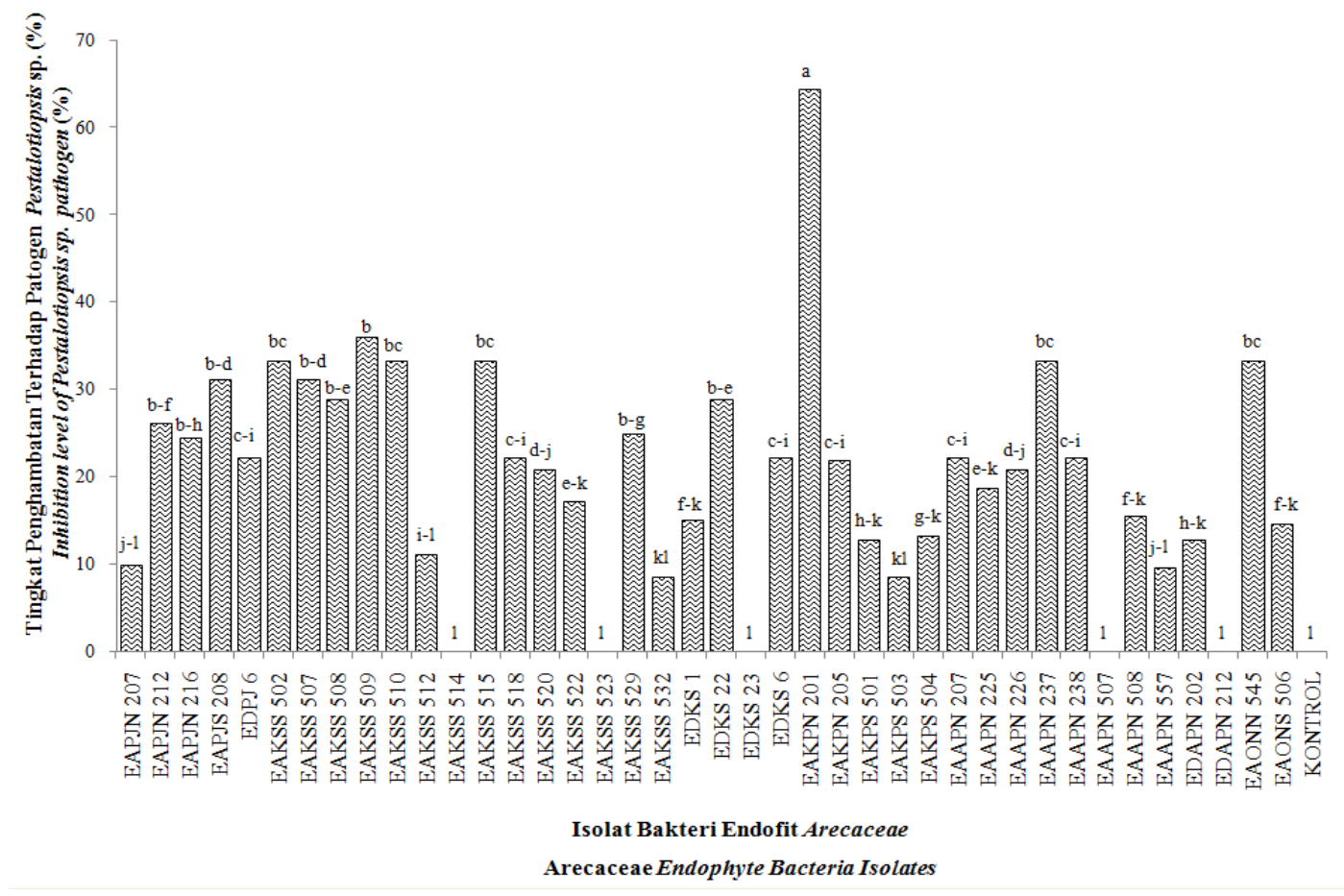

Gambar 3. Tingkat penghambatan isolat bakteri endofit Arecaceae terhadap pertumbuhan patogen Pestalotiopsis sp. secara in vitro (huruf yang sama pada diagram batang berarti tidak berbeda nyata menurut uji selang berganda Tukey pada $\alpha=0.05$ ).

Figure 3. Arecaceae endophytic bacteria inhibition rate on growth of Pestalotiopsis sp. in vitro (bars followed by similar letters show no significant difference according to Tukey's multiple range test at $\alpha=0.05$ ).

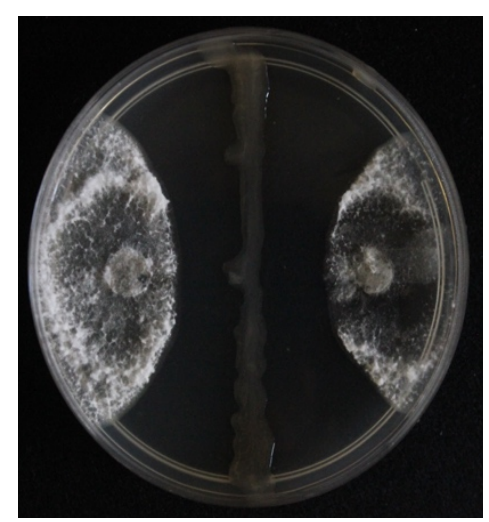

Gambar 4. Penghambatan pertumbuhan miselium cendawan bercak Pestalotiopsis sp. oleh isolat bakteri endofit Arecaceae EAKPN 201.

Figure 4. Inhibitory development of Pestalotiopsis sp. mycelium by Arecaceae endophytic bacteria EAKPN 201.

Berdasarkan data pada Tabel 2 diketahui bahwa beberapa isolat memiliki peranan penting dalam memproduksi senyawa kimia atau metabolit tertentu yang berguna bagi tanaman. Isolat EAAPN 237 menghasilkan hormon auksin yang lebih tinggi dibandingkan dengan 6 isolat bakteri endofit lainnya. Bakteri endofit mendukung pertumbuhan tanaman melalui produksi regulator pertumbuhan tanaman seperti auksin, sitokinin dan giberelin (Compant et al., 2010).
Isolat EAKPN 201, EAAPN 237 dan EAONN 545 menunjukkan kemampuan produksi kitinase yang tinggi ditunjukkan dengan terbentuknya zona bening yang lebar pada media agar kitin. Begitu pula isolat EAKPN 201 yang menunjukkan kemampuan penambatan nitrogen, mampu melarutkan fosfat agar tersedia bagi tanaman, juga mampu memproduksi IAA, kitinase, sekaligus mampu menambat nitrogen dari udara. 
Tabel 2. Beberapa karakter fisiologi 7 bakteri endofit potensial.

Table 2. Some physiological characters of 7 potential endophytic bacteria

\begin{tabular}{|c|c|c|c|c|}
\hline $\begin{array}{l}\text { Isolat bakteri endofit/ } \\
\text { Endophyte bacteria isolates }\end{array}$ & 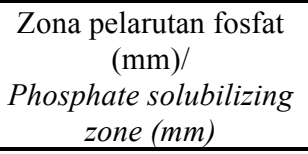 & $\begin{array}{l}\text { Produksi IAA } \\
(\mathrm{ppm}) / \\
\text { IAA production } \\
(\text { ppm) }\end{array}$ & $\begin{array}{l}\text { Zona kitinolitik } \\
(\mathrm{mm}) / \\
\text { Chitinolytic zone } \\
(\mathrm{mm})\end{array}$ & $\begin{array}{l}\text { Penambat } \\
\text { nitrogen/ } \\
\text { Nitrogen } \\
\text { fixing }\end{array}$ \\
\hline EAKPN 201 & 9,67 & 6,85 & Th & + \\
\hline EAKSS 509 & 4,33 & 6,28 & 2 & - \\
\hline EAKSS 502 & 6,67 & 6,4 & 2 & - \\
\hline EAKSS 515 & 0 & 4,19 & 0 & - \\
\hline EAKSS 510 & 5,33 & 6,85 & 0 & - \\
\hline EAAPN 237 & 2,33 & 12,32 & 4 & - \\
\hline EAONN 545 & 0 & 4,18 & 4 & - \\
\hline
\end{tabular}

Fosfat (P) merupakan salah satu unsur hara penting yang dibutuhkan bagi pertumbuhan tanaman. Aplikasi fosfat dalam jumlah besar di tanah dalam bentuk pupuk kimia tidak dengan mudah dan cepat dapat dimanfaatkan oleh tanaman. Tanaman memerlukan bantuan mikroorganisme untuk memproses fosfat sehingga tersedia bagi tanaman. Mikroorganisme tertentu mampu melarutkan fosfat yang tidak tersedia menjadi fosfat tersedia bagi tanaman (Chen et al. 2006; Taurian et al., 2010). Bakteri endofit yang mampu melarutkan fosfat, mengeluarkan senyawa organik berberat molekul rendah dengan gugus hidroksil dan karboksil yang mampu mengkelat ion positif pada fosfat kemudian mengkonversinya menjadi bentuk fosfat yang lebih sederhana sehingga dapat digunakan oleh tanaman (Sarker et al., 2014). Pada penelitian yang lain Chen et al., (2006) melaporkan setidaknya terdapat 8 jenis asam organik yang dihasilkan bakteri pelarut fosfat diantaranya citric acid, gluconic acid, lactic acid, succinic acid, propionic acid dan 3 jenis asam organik lain yang tidak teridentifikasi. Pertumbuhan dan perkembangan tanaman yang sangat dipengaruhi oleh unsur fosfat antara lain perkembangan perakaran, batang, ranting, bunga dan pembentukan benih, produksi buah, penambatan nitrogen pada legum, hingga resistensi terhadap penyakit tanaman (Khan et al., 2009).

Bakteri penambat nitrogen dapat menambat nitrogen dari atmosfer karena kemampuannya dalam memproduksi enzim spesifik di dalam sel (intraseluler) yang dikenal sebagai nitrogenase. Nitrogenase disusun oleh dua komponen yang saling menunjang yaitu protein $\mathrm{Fe}$ (komponen I) dan protein Mo-Fe (komponen II). Mikroba kemudian mensekresikan nitrogen yang ditambat dari atmosfer ke lingkungan dalam bentuk amonium (Franche et al., 2009; Hartono \& Jumadi, 2014; Ji et al., 2014).

Kitin merupakan polimer penyusun dinding sel cendawan yang dapat terdegradasi dengan adanya kitinase (Dai et al., 2011). Kitinase merupakan enzim hidrolitik pendegradasi kitin yang dapat berperan sebagai antifungi pengendali hayati cendawan patogen (Fadhil et al., 2014).

Kitin dimanfaatkan oleh bakteri dengan bantuan enzim ektraseluler kitinase yang merupakan metabolit primer, selanjutnya diperoleh $\mathrm{N}$ asetilglukosamin sebagai sumber karbon bagi pertumbuhan bakteri, hal ini ditandai dengan terbentuknya zona bening pada media kitin agar (Toharisman et al., 2005).

\section{Kesimpulan}

Sebanyak 64 isolat bakteri endofit akar dan daun tanaman Arecaceae diantaranya tanaman Pejibaye ( $B$. gasipaes), Kelapa Kopyor (C. nucifera), Kelapa Sawit (E. guinensis), Aren (A. pinnata) dan Nibung ( $O$. filamentosa) menunjukkan kemampuan penghambatan terhadap cendawan patogen Pestalotiopsis sp. Pengujian keamanan hayati menunjukkan bahwa 40 isolat bakteri endofit Arecaceae dari 64 isolat yang diujikan tidak bersifat patogen baik bagi tanaman maupun bagi hewan dan manusia. Hasil uji antibiosis menunjukkan 7 isolat bakteri endofit potensial karena memiliki daya penghambatan terhadap pertumbuhan miselium cendawan Pestalotiopsis sp. secara in vitro dibandingkan dengan isolat lain yang diujikan. Isolat tersebut yakni isolat EAKPN 201, EAKSS 509, EAKSS 502, EAKSS 510, EAKSS 515, EAAPN 237, dan EAONN 545. Isolat-isolat tersebut memiliki kemampuan pelarutan fosfat, kemampuan memproduksi IAA dan, kitinase, dan kemampuan mengikat nitrogen yang sangat berpengaruh terhadap pertumbuhan tanaman. Daya penghambatan terhadap patogen Pestalotiopsis sp. tertinggi dihasilkan oleh isolat EAKPN 201 sebesar 64,4\%.

\section{Daftar Pustaka}

Ariyanti D (2010). Karakterisasi hemolisin dan analisis amplified fragment length polymorphism (AFLP) Staphylococcus aureus isolat pangan olahan asal hewan [Disertasi]. Yogyakarta: Universitas Gadjah Mada. 
Bordiec S, S Paquis, H Lacroix, S Dhondt, EA Barka, S Kauffmann, P Jeandet, F Mazeyrat-Gourbeyre, C Clément, F Baillieul \& S Dorey (2011). Comparative analysis of defence responses induced by the endophytic plant growthpromoting rhizobacterium Burkholderia phytofirmans strain PsJN and the non-host bacterium Pseudomonas syringae pv. pisi in grapevine cell suspensions. Journal of Experimental Botany, 62(2), 595-603.

Chen F, M Wang, Y Zheng, J Luo, X Yang \& X Wang (2010). Quantitative changes of plant defense enzymes and phytohormone in biocontrol of cucumber Fusarium wilt by Bacillus subtilis B579. World. J. Microbiol Biotechnol, 26, 675684.

Compant S, C Clément \& A Sessitsch (2010). Plant growth-promoting bacteria in the rhizo-and endosphere of plants: their role, colonization, mechanisms involved and prospects for utilization. Soil Biology and Biochemistry, 42(5), 669-678

Dai DH, WL Hu, G Huang \& W Li (2011). Purification and characterization of a novel extracellular chitinase from thermophilic Bacillus sp. Bul. Afr J Biotechnol., 10, 2476-2485.

Daungsa-ard C, P Athipunyakom \& RG Shivas (2011). CURVULARIA (Curvularia oryzae)[Internet]. [diunduh 2016 Sep 7].Tersedia pada: www.padil.gov.au/thai- bio/ pest/ main/ $140456 / 30855$.

Eris DD, A Munif, BPW Soekarno \& A Purwantara (2017). Kelimpahan dan keragaman bakteri endofit asal tanaman Arecaceae (Pejibaye (Bactris Gasipaes), Kelapa Sawit (Elaeis Guinensis), Kelapa Kopyor (Cocos Nucifera), Aren (Arenga Pinata) dan Nibung (Oncosperma Filamentosa). Di dalam : M. Nadzirum dan G.P. Mahardika (eds). Prosiding Seminar Nasional Perlindungan Tanaman Perkebunan. Seminar Nasional Perlindungan Tanaman Perkebunan "Perlindungan Tanaman Perkebunan untuk Kesejahteraan Rakyat dan Bangsa"; 2016 Okt 25; Bogor, pp.168-194.

Etesami H, HA Alikhani \& HM Hosseini (2015). Indole-3-Acetic Acid (IAA) production trait, a useful screening to select endophytic and rhizosphere competent bacteria for rice growth promoting agents. Methods X, 2, 72-78.

Evidente A, MC Zonno, A Andolfi, C Troise \& A Cimmino (2012). Phytotoxic [alpha]-pyrones produced by Pestalotiopsis guepinii, the causal agent of hazelnut twig blight. Journal of Antibiotics, 65(4), 203.

Fadhil L, A Kadim \& A Mahdi (2014). Production of chitinase by Serratia marcescens from soil and its antifungal activity. J Nat Sci Re., 4, 80-86.
Franche C, K Lindström \& C Elmerich (2009). Nitrogen-fixing bacteria associated with leguminous and non-leguminous plants. Plant and Soil, 321(1-2), 35-59.

Ghevariya K \& P Desai (2014). Rhizobacteria of sugarcane: In vitro screening for their plant growth promoting potentials. Research Journal of Recent Sciences, 2277, 2502.

Hallmann J, A Quadt-Hallmann, W Miller, R Sikora \& S Lindow (2001). Endophytic colonization of plantsby the biocontrol agent Rhizobium etli G12 in relation to Meloidogyne incognita infection. Phytopathology, 91(4), 415-422

Hariprasad P, S Divakara \& S Niranjana (2011). Isolation and characterization of chitinolytic rhizobacteria for the management of Fusarium wilt in tomato. Crop Protection, 30(12), 16061612.

Hartono \& O Jumadi (2014). Seleksi dan karakterisasi bakteri penambat nitrogen non simbiotik pengekskresi amonium pada tanah pertanaman jagung (Zea mays L.) dan padi (Oryza sativa L. ) asal Kabupaten Barru, Sulawesi Selatan, Indonesia. Jurnal Sainsmat, 3(2), 143153.

Ji SH, MA Gururani \& SC Chun (2014). Isolation and characterization of plant growth promoting endophytic diazotrophic bacteria from Korean rice cultivars. Microbiological research, 169(1), 83-98.

Khan AL, BA Halo, A Elyassi, S Ali \& K Al-Hosni (2016). Indole acetic acid and ACC deaminase from endophytic bacteria improves the growth of Solanum lycopersicum. Electronic Journal of Biotechnology, 19(3), 58-64.

Kittimorakul J, C Porn suriya, A SunPapao \& V Petcharat (2013). Survey and incidence of leaf blight and leaf spot disease of oil palm seedling in southern Thailand. Plant Pathology Journal, 12(3), 149-153.

Leelasuphakul W, P Hemmanee \& S Chuenchitt (2008). Growth inhibitory properties of Bacillus subtilis strains and their metabolites against the green mold pathogen (Penicillium digitatum Sacc.) of citrus fruit. Postharvest Biol Technol., 48, 113-121.

Liu AR, T Xu \& LD Guo (2007). Molecular and morphological description of Pestalotiopsis hainanensis sp. nov., a new endophyte from a tropical region of China. Fungal Diversity, 24, 2336.

Lodewyckx C, J Vangronsveld, F Porteous, ER Moore \& S Taghavi (2002). Endophytic bacteria 
and their potential applications. Critical Reviews in Plant Sciences, 21(6), 583-606.

Mudatsir M (2014). Penggunaan darah kadarluarsa sebagai media isolasi dan identifikasi Streptococcus faecalis. Jurnal Biologi Edukasi, 2(1), 36-41.

Munif A, S Wiyono \& Suwarno (2012). Isolasi bakteri endofit asal padi gogo dan potensinya sebagai agens biokontrol dan pemacu pertumbuhan. Jurnal Fitopatologi Indonesia, 8(3), 57-64.

Nagata T, Y Ando \& A Hirota (1992). Phytotoxins from tea gray blight fungi, Pestalotiopsis longiseta and Pestalotiopsis theae. Bioscience, Biotechnology, and Biochemistry, 56(5), 810-811.

Rahman S, S Adhikary, S Sultana, S Yesmin \& N Jahan (2013). In vitro evaluation of some selected fungicides against Pestalotia palmarum (Cooke.) causal agent of grey leaf spot of coconut. J Plant Pathol Microb, 4(9).

Sarker A, NM Talukder \& MT Islam (2014). Phosphate solubilizing bacteria promote growth and enhance nutrient uptake by wheat. Plant Science Today, 1(2), 86-93.

Schaad NW, JB Jones \& W Chun (2001). Laboratory guide for identification of plant pathogenic bacteria. St. Paul, APS press. pp.118

Suardana IW, IH Utama \& MH Wibowo (2014). Identifikasi Escherichia coli O157: H7 dari feses ayam dan uji Profil hemolisisnya pada media agar darah. Jurnal Kedokteran Hewan-Indonesian Journal of Veterinary Sciences, 8(1), 1-5.
Sukamto ITN (2001). Kelapa kopyor: pembibitan. budidaya. Jakarta, Penebar Swadaya.pp.21

Suriaman E (2010). Potensi bakteri endofit dari akar tanaman kentang (Solanum tuberosum) dalam memfiksasi N2 di udara dan menghasilkan hormon iaa (indole acetid acid) secara in vitro. [skripsi] Malang, UIN.

Suwannarach N, K Surajit, J Kumla, B Bussaban \& S Lumyong (2013). First report of leaf spot disease on oil palm caused by Pestalotiopsis heae in Thailand. J. General Plant Pathol., 79, 272-279.

Taurian T, MS Anzuay, JG Angelini, ML Tonelli \& L Ludueña (2010). Phosphate-solubilizing peanut associated bacteria: screening for plant growthpromoting activities. Plant and Soil, 329(1-2), 421-431.

Toharisman A, MT Suhartono, BM Spindler, JK Hwang, \& YR Pyun (2005). Purification and characterization of a thermostable chitinase from Bacillus licheniformis MB-2. World Microbiol Biotechnol., 21(5),730-738.

Vassilev N, M Vassileva \& I Nikolaeva (2006). Simultaneous P-solubilizing and biocontrol activity of microorganisms: potentials and future trends. Applied Microbiology and Biotechnology, 71(2), 137-144.

Xu J, SS Ebada \& P Proksch (2010). Pestalotiopsis a highly creative genus chemistry and bioactivity of secondary metabolites. Fungal Diversity, 44(1), $15-31$. 
